\title{
A note on the effect of energy sources on duodenal flow of fatty acids and bacterial nitrogen in sheep
}

\author{
A. Potkański' ${ }^{1}$ J. Kowalczyk ${ }^{2}$, M. Szumacher-Strabel ${ }^{1}$, A.Cieślak' \\ and M. Czauderna ${ }^{2}$
}

'Department of Animal Nutrition and Feed Management, August Cieszkowski Agricultural University

Wolyniska 33, 60-637 Poznań, Poland

${ }^{2}$ The Kielanowski Institute of Animal Physiology and Nutrition,

Polish Academy of Sciences

05-110 Jablonna, Poland

(Received 29 September 2000; revised version 10 March 2001; accepted 20 Apri1 2001)

\section{ABSTRACT}

The effect of energy source in diets on duodenal flow of bacteria $\mathrm{N}$ and fatty acids was measured in an experiment on four sheep in a $4 \times 4$ Latin square design. The basal diet for control animals consisting of $40 \%$ concentrate and $60 \%$ meadow hay was supplemented for experimental animals with $6 \%$ of rape sced oil, saccharose, or starch as an additional energy source. The energy supplement did not change rumen $\mathrm{pH}(\mathrm{P}>0.05)$, but decreased $(\mathrm{P}<0.05)$ rumen ammonia-N from 41.6 $\mathrm{mmol}$ in the control group to $15.6,17.5$ and $23.3 \mathrm{mmol}$ in groups receiving rape secd oil, saccharose, or starch, respectively. A similar declining tendency was found for total volatile fatty acids and the majority of individual ones. Dusodenal flow of bacteria $\mathrm{N}$ calculated from 2,6-diaminopimclic acid content was not significantly affected by the diet. The ratio of 2,6-diaminopimelic acid to total nitrogen content in digesta was lower in control than experimental groups, indicating a higher proportion of bacterial protein in the digesta of animals recciving additional energy in diets. The proportion of unsaturated as well as saturated fatty acids in the digesta of animals fed diets supplemented with starch was lower $(\mathrm{P}<0.05)$ than in the remaining groups. The duodenal digesta of animals fed the diet supplemented with rape seed oil contained significantly higher $(\mathrm{P}<0.05)$ polyunsaturated $\mathrm{n}-3$, monounsaturated and saturated fatty acid proportions compared with the remaining groups. These results demonstrate that feeding sheep with diets supplemented with energy decreases ammonia and volatile fatty acid levels in the rumen fluid whereas only addition of rape seed oil increases the proportions of polyunsaturated $n-3$, monounsaturated and saturated fatty acid in the fat of duodenal digesta.

KEY WORDS: sheep, energy source, fat, saccharose, starch, fatty acids, DAPA 


\section{INTRODUCTION}

Ruminants usually lose body weight during the early lactation period as a result of body energy being drawn to satisfy requirements for increased milk production (Chouinard et al., 1998). Supplementing the diet with starch or fat as energy sources may overcome limitations in energy supply, however, fat may restrict microbial protein production in the rumen (Kowalczyk et al., 1977; Khorasani and Kennelly, 1998). Energy sources increase the energy density of the diet but their supply to the diet affects the amount and composition of products such as milk or meat. Beef and dairy products suffer from a negative health image related to their lipid fraction (Demeyer and Doreau, 1999). The amount of saturated fat in the diet correlates more strongly with the incidence of cardiovascular diseases than total fat intake. In contrast, the consumption of unsaturated fatty acids appears to be beneficial, since it is inversely correlated with the plasma cholesterol concentration and the risk of myocardial infarction (Windler, 2000). Brzóska et al. (1998) indicated a direct correlation between the levels of dietary $\omega 3$ (n-3) fatty acids and reduced incidence of hypertension, atherosclerosis, and/or cardiovascular diseases. Ruminant products of appropriate fatty acid composition might be a source of health-promoting substances, which are beneficial in prevention and treatment of various diseases ranging from headache to heart problems, cancer and oxidative stress (Chen et al., 1999). From this point of view, the fatty acid composition of fat in the diet or reaching the duodenum might be more important than the amount of fat as an energy source in the diet. The fatty acid composition of animal products such as meat or milk is correlated with fatty acids reaching the duodenum and their absorption in the small intestine. Moreover, fatty acids ingested with dietary fat undergo transformation in the reticulo-rumen through biohydrogenation processes that derive desirable conjugated isomers of linoleic acid (Bessa et al., 2000).

The aim of this study was to investigate the effect of different energy sources in the diet for sheep on fatty acid composition in duodenal digesta and their influence on microbial protein synthesis in the rumen.

\section{MATERIAL AND METHODS}

\section{Animals and diets}

The experiment was carried out on four sheep of $40 \pm 4 \mathrm{~kg}$ body weight fitted with permanent ruminal and duodenal cannulas in a $4 \times 4$ Latin square design with 16-day periods. The sheep were housed in individual cages with free access to fresh water and fed a $900 \mathrm{~g}$ daily ration in two equal portions at 08.00 and 18.00 . The basal diet for control animals consisting of $40 \%$ concentrate and $60 \%$ mea- 
dow hay and containing 5.04 MJ NE and $132 \mathrm{~g}$ crude protein per $\mathrm{kg}$ was supplemented with $54 \mathrm{~g}$ of rape seed oil, $54 \mathrm{~g}$ saccharose or $54 \mathrm{~g}$ starch, as additional sources of energy. The animals were adapted to the diet for 14 days and in the last 2 days of each period samples for analysis were collected.

\section{Sampling and analysis}

Feeds were sampled weekly throughout the experiment. Samples of duodenal digesta representing $10 \%$ of total digesta passage were collected continuously from sheep for $2 \mathrm{~d}$ starting at $08.00 \mathrm{~h}$ on day 15 of each period. Composed samples were thawed, homogenized and lyophilized for analysis for fatty acid composition and 2,6-diaminopimelic acid (DAPA) content. Samples of rumen fluid were taken before feeding, 3 and $6 \mathrm{~h}$ after feeding, using a simple device described by Szumacher-Strabel et al. (1998). In the rumen liquid samples taken before the morning feeding, 3 and $6 \mathrm{~h}$ after feeding, $\mathrm{pH}$ was measured potentiometrically, ammonia concentration according to Conway (1962) and volatile fatty acid concentration and their proportions according to Ziołecki and Kwiatkowska (1973) using gas chromatography Chrom 5 equipment. DAPA acid concentration in duodenal digesta was analyzed as a marker of bacterial protein content according to Czauderna and Kowalczyk (1999) using an HPLC method with pre-column derivatization. Long-chain fatty acids were determined in duodenal digesta according to Czauderna at al. (2001).

\section{Statistical analysis}

All data were analyzed using SAS procedures (User's Guide, 1990).

\section{RESULTS}

The mean concentrations of rumen $\mathrm{NH}_{3}-\mathrm{N}$, VFA and $\mathrm{pH}$ were affected by the diets (Table 1). All supplemented energy sources significantly decreased ammonia and VFA levels in the rumen liquids $(\mathrm{P}<0.05)$ but the $\mathrm{pH}$ value was only slightly higher compared with that of the control group. The proportion of propionate to acetate in the rumen liquid of animals receiving starch as an energy supplement was higher than in the remaining groups, but the proportion of butyrate to acetate was higher in the rumen of animals receiving diets supplemented with saccharose or starch than in the rape seed oil or control group.

The concentration of all determined long-chain fatty acids (unsaturated and saturated) in duodenal digesta was significantly lower on the diet supplemented with starch $(\mathrm{P}<0.05)$ whereas the diet supplemented with rape seed oil caused an 
TABLE 1

Total and individual volatile fatty acid, ammonia- $\mathrm{N}$ concentration, $\mathrm{mmol} / \mathrm{L}$, and $\mathrm{pH}$ of the rumen liquid of animals fed diets supplemented with different sources of energy

\begin{tabular}{|c|c|c|c|c|}
\hline \multirow{2}{*}{ Energy source } & \multicolumn{4}{|c|}{ Group } \\
\hline & control & rape seed oil & saccharose & starch \\
\hline Ammonia $N$ & $41.7^{\mathrm{ab}}$ & $15.6^{\mathrm{a}}$ & $17.50^{b}$ & $23.3^{\mathrm{c}}$ \\
\hline $\mathrm{pH}$ & 6.11 & 6.50 & 6.59 & 6.47 \\
\hline $\begin{array}{l}\text { Total VFA } \\
\text { proportion, } \%\end{array}$ & $110.2^{\text {abc }}$ & $79.9^{a}$ & $73.3^{b}$ & $83.6^{c}$ \\
\hline acctate & $69.9^{\mathrm{abc}}$ & $52.1^{a}$ & $43.6^{b}$ & $49.0^{\mathrm{c}}$ \\
\hline propionate & $18.9^{a b c}$ & $14.2^{\mathrm{s}}$ & $11.6^{\mathrm{b}}$ & $15.8^{\mathrm{c}}$ \\
\hline butyrate & $16.7^{\mathrm{abc}}$ & $10.5^{\mathrm{a}}$ & $13.3^{b}$ & $15.0^{\mathrm{c}}$ \\
\hline isobutyrate & $1.3^{\mathrm{abc}}$ & $0.8^{\mathrm{a}}$ & $0.7^{b}$ & $1.3^{\mathrm{c}}$ \\
\hline isovalerate & $2.3^{\mathrm{abc}}$ & $1.4^{\text {ad }}$ & $3.2^{\mathrm{bde}}$ & $1.6^{\mathrm{ce}}$ \\
\hline valerate & 0.9 & 0.8 & 0.9 & 0.9 \\
\hline
\end{tabular}

a.b,c,d,e values with the same letters are significantly different $(P<0.05)$

increase in the concentration of PUFA n-3, MUFA and SFA ( $\mathrm{P}<0.05$; Table 2$)$. The fatty acid content in duodenal digesta of animals fed the diet with saccharose was similar as in control group.

Duodenal flow of microbial protein with digesta was similar in all experimental groups and higher, but not significantly $(\mathrm{P}>0.05)$, than in control animals. The percentage of DAPA in duodenal digesta protein was also slightly higher in experimental animals than in control groups (Table 3 ).

TABLE 2

Long chain fatty acid concentration in duodenal digesta of sheep fed diet supplemented with different energy sources, $\mathrm{mg} / 100 \mathrm{~g}$ digesta

\begin{tabular}{lcccc}
\hline & \multicolumn{4}{c}{ Group } \\
\cline { 2 - 5 } & control & rape seed oil & saccharose & starch \\
\hline PUFA $^{\prime}$ n-3 & $42.2^{\text {ab }}$ & $53.1^{\text {ace }}$ & $44.6^{\text {de }}$ & $28.6^{\text {bcd }}$ \\
PUFA n-6 & $334^{\text {ac }}$ & $325^{\mathrm{b}}$ & $315^{\mathrm{c}}$ & $165^{\text {abc }}$ \\
PUFA & $376^{\mathrm{a}}$ & $378^{\mathrm{b}}$ & $360^{\mathrm{c}}$ & $194^{\text {abc }}$ \\
MUFA $^{2}$ & $493^{\text {ac }}$ & $634^{\text {abc }}$ & $505^{\text {bd }}$ & $265^{\text {cdc }}$ \\
SFA $^{3}$ & $519^{\text {ac }}$ & $1506^{\text {abc }}$ & $569^{\text {bd }}$ & $33 !^{\text {cde }}$ \\
\hline
\end{tabular}

a.t.c.d,e values with the same letters are significantly different $(P<0.05)$

1 polyunsaturated fatty acids

2 monounsaturated fatty acids

${ }^{3}$ saturated fatty acids 
TABLE 3

Content of 2,6-diaminopimelic acid (DAPA) in duodenal digesta and protein

\begin{tabular}{lcccc}
\hline & \multicolumn{4}{c}{ Group } \\
\cline { 2 - 5 } & control & rape seed oil & saccharose & starch \\
\hline DAPA, g/d & 0.33 & 0.42 & 0.32 & 0.36 \\
DAPA in protein, $\%$ & 0.69 & 0.82 & 0.79 & 0.79 \\
\hline
\end{tabular}

\section{DISCUSSION}

Dietary fat enhances energetic efficiency in high producing ruminants by increasing total energy intake generating ATP more efficiently than carbohydrateorigin volatile fatty acids or protein, by direct incorporation into the product, and by promoting nutrient partition toward milk production (Palmquist, 1994). However, the use of large amounts of fat, in contrast to easily fermentable carbohydrate, for ruminants is limited by numerous factors such as the inhibitory effect on rumen microorganism growth, changes of rumen fermentation pattern, decrease of fibre digestion and nutrient absorption (Kowalczyk et al., 1977).

Dietary fat supplementation increases the energy density of the diet, but its influence on nutrient supply to the animal depends on the digestibility of the fat source and on the effects of the added fat on intake, rumen fermentation, and digestibility of other dietary components (Khorasani and Kennelly, 1998). Similar reactions are found with other energy sources.

The results of Kalscheur et al. (1997) indicated that the flow of trans-C-18:1 into the duodenum was higher for cows fed diets supplemented with fat than for cows fed a control diet ( 283 vs $64 \mathrm{~g} \mathrm{~d}^{-1}$ ). The present experiment confirmed this result, as addition of rape seed oil into the diet caused a significant increase of the amount of all fatty acids entering the duodenum compared with controls. Also Elliot et al. (1999) observed that flows of total fatty acids were greater by supplemental fat and were even greater than their intake. This effect confirms that fat is rather poorly absorbed from the forestomachs. A different effect was obtained when starch, as a source of energy, was added to the diet as the amount of fatty acids entering the duodenum was in this case smaller than in animals fed a control diet, indicating that part of the fat provided with feed was already utilized in the developed stomach of ruminants before reaching the duodenum. The amount of all fatty acids entering the duodenum of animals fed a diet supplemented with saccharose was similar compared to the control diet (Table 2). The results obtained in this experiment clearly demonstrate that the type of energy provided to ruminants with the feed ration may affect the amount of unsaturated and saturated fatty acids reaching the duodenum. 
Duodenal flows of bacterial $\mathrm{N}$ were not significantly affected by the diet but in all experimental groups DAPA tended to increase in comparison with the control group (Table 3). The results of the experiment carried out by Hussein et al. (1996) also indicated that fat supplementation from canola seed (at $5 \%$ of dietary DM), in either form, had no effects on ruminal $\mathrm{N}$ metabolism or flows of amino acids to the duodenum and suggest that treated whole canola seed may stimulate ruminal bacterial protein synthesis. In our previous experiment on sheep given different energy sources, we did not find a deleterious effect of fats on microbial synthesis, which tended even to be slightly higher than in animals fed control diets (Szumacher-Strabel, 1998). These results indicate that the energy available from the control diet was not a limiting factor for microbial synthesis in the rumen.

The concentrations of ammonia $\mathrm{N}$ and VFA in the rumen were significantly depressed by the experimental diet related to the controls, but the $\mathrm{pH}$ of rumen fluid did not differ significantly between the groups of sheep (Table 1). All values of indices obtained for rumen fluid fell well within physiological values. Similarly as in experiments on sheep carried out by Kowalczyk et al. (1977) and Schauf et al. (1992), we also observed a tendency to depress rumen ammonia concentration by dietary energy sources. The lowest ammonia level in the rumen of sheep fed the diet supplemented with fat compared with other groups of sheep was caused by relatively high addition of rape seed oil. A similar effect was found on the dict containing saccharose, which is fermented, delivering energy for bacterial synthesis in the rumen faster than starch, therefore the ammonia level differed significantly. The concentration of total VFA in the rumen was significantly lower in sheep receiving the experimental diet compared with the respective values in the control group, and corresponded to the lowest $\mathrm{pH}$ value.

The molar proportion of acetate was similar in the rumen fluid of sheep fed control and rape seed oil-supplemented diets and higher than in those fed diets with saccharose or starch, but the butyrate proportion was the lowest (Table 1) in the rumen fluid of sheep fed the control diet, which indicates a different type of fermentation in the rumen of animals fed diets with different sources of supplemental energy.

\section{CONCLUSIONS}

The results of this experiment indicate that supplementing about $6 \%$ of fat or easily fermentable carbohydrate, saccharose or starch, as energy sources to diets for sheep depresses ammonia and volatile fatty acid levels in the rumen fluid but does not significantly influence the amount of bacterial protein reaching the duodenum. More saturated and unsaturated fatty acids are delivered to the duodenum with digesta when rape seed oil than when saccharose or starch are added to the 
diets as an energy source. Supplementing diets for ruminants with vegetable oils containing desirable unsaturated fatty acids creates the possibility of their passage to the small intestine and their absorption, with possible improved meat and milk quality.

\section{REFERENCES}

Bessa R.J.B., Santos-Silva J., Ribeiro J.M.R., Portugal A.V., 2000. Reticulo-rumen biohydrogenation and the enrichment of ruminant edible products with linoleic acid conjugated isomers. Livest. Prod. Sci. 61, 201-211

Brzóska F., Gąsior R., Brzóska B., Zyzak W., 1998. Modification of the fatty acid profile of cows milk for human needs by feeding Ca-fatty acid salt of linseed or fish oil. EAAP Publication, $49^{\text {th }}$ Annual Meeting of the EAAP, Book of Abstracts No 4, p. 84

Chen Y., Zhu N.Q., Lo C.Y., Wang M.F., Ho C.T., 1999. Process-induced health-promoting substances in foods [Review]. Food Rev. Int. 15, 473-501

Chouinard P.Y., Girard V., Brisson G.J., 1998. Fatty acid profile and physical properties of milk fat from cows fed calcium salts of fatty acids with varying unsaturation. J. Dairy Sci. 81, 471-481

Conway E.J., 1962. Microdiffusion Analysis and Volumetric Error. Crosby Lockwood, London

Czauderna M., Kowalczyk J., 1999. Determination of 2,6-diaminopimelic acid in bacteria, ruminal and duodenal digesta using HPLC with fluorescence or UV detection. J. Anim. Feed Sci. 8, 273-288

Czauderna M., Kowalczyk J., Potkański A., Szumacher-Strabel M., Chojecki G., 2001. Quantification of conjugated linoleic acid and other essential fatty acids in ovine meat, milk, fat and intestinal digesta. J. Anim. Feed Sci. 10, Suppl. 1, (in press)

Demeyer D., Doreau M., 1999. Targets and procedures for altering ruminant meat and milk lipids. Proc. Nutr. Soc. 58, 593-607

Elliott J.P., Drackley J.K., Beaulieu A.D., Aldrich C.G., Merchen N.R., 1999. Effects of saturation and estrification of fat sources on site and extent of digestion in steers: digestion of fatty acids, triglycerides, and energy. J. Anim. Sci. 77, 1919-1929

Hussein H.S., Merchen N.R., Fahey G.C., 1996. Effects of forage percentage and canola seed on ruminal protein metabolism and duodenal flows of amino acids in steers. J. Dairy Sci. 79, 98-104

Kalscheur K.F., Teter B.B., Piperova L.S., Erdman R.A., 1997. Effect of fat source on duodenal flow of trans-C-18/1 fatty acids and milk fat production in dairy cows. J. Dairy Sci. 80, 2115-2126

Khorasani G.R., Kennely J.J., 1998. Effect of added dietary fat on performance, rumen characteristics, and plasma metabolites of midlactation dairy cows. J. Dairy Sci. 81, 2459-2468

Kowalczyk J., Ørskov E.R., Robinson J.J., Stewart C.S., 1977. Effect of fat supplementation on voluntary food intake and rumen metabolism in sheep. Brit. J. Nutr. 37, 251-257

Palmquist D.D., 1994. The role of dietary fats in efficiency of ruminants. J. Nutr. 124, S1377-S1382

SAS, 1990. SAS/STAT Users guide (Release 6.03). SAS Institute Inc., Cary, NC

Schauff D.J., Elliot J.P., Clark J.H., Drackley J.K., 1992. Effects of feeding lactating dairy cows diets containing whole soybeans and tallow. J. Dairy Sci. 75, 1923-1935

Szumacher-Strabel M., Potkański A., Cieślak A., 1998. A note on the effect of rape seed oil supplementation on microbial protein synthesis in sheep. J. Anim. Feed Sci. 7, 293-300

Szumacher-Strabel M., 1998. Microbial protein net synthesis in sheep fed hay-concentrate diets supplemented with different source and level of fat. J. Anim. Feed Sci. 7, 395-404 
Windler E., 2000. The role of nutrition in the prevention of arteriosclerotic cardiovascular disease. Emähr.-Umsch. 47, 21

Ziołecki A., Kwiatkowska E., 1973. Gas chromatography of $C_{1}$ to $C_{5}$ fatty acids in rumen and fermentation media. J. Chromatogr. 80, 250-254

\section{STRESZCZENIE}

Wplyw różnych źródel energii w dawkach na przeplyw kwasów tłuszczowych i kwasu 2,6-dwuaminopimelinowego $w$ dwunastnicy owiec

Doświadczenie przeprowadzono w układzie kwadratu łacińskiego $4 \times 4$ na czterech tryczkach z kaniulami do żwacza i dwunstnicy. Zwierzęta żywiono dawką pokarmową złożoną z siana i mieszanki treściwej (60:40\%) w grupie kontrolncj lub uzupełnionej dla grup doświadczalnych dodatkami energetycznymi - olejem rzepakowym, sacharozą lub skrobią w ilości 6\% suchej masy dawki. Dawkę dzielono na dwie równe części i skarmiano w dwóch odpasach o godzinie 0800 i 1800. W próbach treści żwacza oznaczano poziom azotu amonowego, lotnych kwasów tłuszczowych oraz $\mathrm{pH}$. W próbach treści dwunastnicy reprezentujących dobowy przepływ treści oznaczano wyższe kwasy thuszczowe oraz zawartość kwasu 2,6-dwuaminopimelinowego w celu określenia rozmiaru syntezy białka bakteryjnego w żwaczu. Zastosowane dodatki energetyczne obniżyły istotnic $(\mathbf{P}<0.05)$ poziom azotu amonowego i lotnych kwasów tłuszczowych w żwaczu, nie miały natomiast wpływu na poziom pH i syntezę białka mikroorganizmów. Tłuszcz dodany do dawki zwiçkszył dopływ kwasów tłuszczowych do dwunastnicy $(\mathrm{P}<0.05)$, podczas gdy dodatek skrobi obniżył go. Sacharoza dodana do dawki nie miała wpływu na poziom kwasów tłuszczowych w dwunastnicy. 